\title{
Thermal and light impacts on the early growth stages of the kelp Saccharina angustissima (Laminariales, Phaeophyceae)
}

\author{
Simona Augyte ${ }^{1, *}$, Charles Yarish ${ }^{1}$ and Christopher D. Neefus ${ }^{2}$ \\ ${ }^{1}$ Department of Ecology \& Evolutionary Biology, The University of Connecticut, 1 University Place, Stamford, CT 06901- \\ 2315, USA \\ ${ }^{2}$ Department of Biological Sciences, The University of New Hampshire, 46 College Rd, Durham, NH 03824, USA
}

Anthropogenic disturbances, including coastal habitat modification and climate change are threatening the stability of kelp beds, one of the most diverse and productive marine ecosystems. To test the effect of temperature and irradiance on the microscopic gametophyte and juvenile sporophyte stages of the rare kelp, Saccharina angustissima, from Casco Bay, Maine, USA, we carried out two sets of experiments using a temperature gradient table. The first set of experiments combined temperatures between $7-18^{\circ} \mathrm{C}$ with irradiance at 20,40 , and $80 \mu \mathrm{mol}$ photons $\mathrm{m}^{-2} \mathrm{~s}^{-1}$. The second set combined temperatures of $3-13^{\circ} \mathrm{C}$ with irradiance of 10,100 , and $200 \mu \mathrm{mol}$ photons $\mathrm{m}^{-2} \mathrm{~s}^{-1}$. Over two separate 4-week trials, in 2014 and again in 2015, we monitored gametogenesis, the early growth stages of the gametophytes, and early sporophyte development of this kelp. Gametophytes grew best at temperatures of $8-13^{\circ} \mathrm{C}$ at the lowest irradiance of $10-\mu m o l$ photons $\mathrm{m}^{-2} \mathrm{~s}^{-1}$. Light had a significant effect on both male and female gametophyte growth only at the higher temperatures. Temperatures of 8-15 ${ }^{\circ} \mathrm{C}$ and irradiance levels of $10-100 \mu \mathrm{mol}$ photons $\mathrm{m}^{-2} \mathrm{~s}^{-1}$ were conditions for the highest sporophyte growth. Sporophyte and male gametophyte growth was reduced at both temperature extremes- the hottest and coldest temperatures tested. S. angustissima is a unique kelp species known only from a very narrow geographic region along the coast of Maine, USA. The coupling of global warming with high light intensity effects might pose stress on the early life-history stages of this kelp, although, as an intertidal species, it could also be better adapted to temperature and light extremes than its subtidal counterpart, Saccharina latissima.

Key Words: gametophyte; irradiance; kelp; north Atlantic; Saccharina angustissima; sporophyte; temperature

\section{INTRODUCTION}

Large subtidal kelps are critical to near shore ecosystems. Kelps form habitat structure, nursery grounds, food for invertebrates and pelagic organisms, and buffer the shoreline from storms (Steneck et al. 2002, Smale et al. 2013). Macroalgal detritus fuels various food webs and is an important nutrient source for herbivores and detritivores (Krumhansl and Scheibling 2012, Duggins et al. 2016). In economic terms, these ecosystem services have been valued at billions of dollars annually (Kim et al. 2015, Rose et al. 2015, Krumhansl et al. 2016). Several kelp species are economically important for food and alginates (Kim et al. 2017, Wells et al. 2017) including Saccharina japonica in Asian countries. In the North Atlantic of the USA, the key species used for the developing seaweed aquaculture industry is Saccharina latissima, or sugar kelp.
(1) $\$$ This is an Open Access article distributed under the terms of the Creative Commons Attribution Non-Commercial License (http://creativecommons.org/licenses/by-nc/3.0/) which permits unrestricted non-commercial use, distribution, and reproduction in any medium, provided the original work is properly cited.
Received December 11, 2018, Accepted May 12, 2019

* Corresponding Author

E-mail: simona.augyte@uconn.edu

Tel: +1-203-251-8530, Fax: +1-203-251-9534 
Sea-surface temperature (SST) is a primary factor driving macroalgal biogeographic distributions in the marine intertidal and, along with light and nutrient requirements, confine macroalgae to the shallow, photic zones (Lüning 1990, Adey and Steneck 2001, Steneck et al. 2002). Evidence is growing that kelp habitats are under threat from multiple stressors including warming SST temperatures, pollution, overharvesting and other anthropogenic disturbances that combined can have major consequences for the structure and function of near-shore coastal ecosystems (Smale et al. 2013, Krumhansl et al. 2016). Under some current climate change scenarios, kelps appear to be at risk in some environments; therefore, it is critical to recognize the photosynthetic responses of kelp to temperature variations to better understand resilience of these important habitatforming species (Colvard et al. 2014, Krumhansl et al. 2016). In the past few decades, studies have shown the retreat of northern hemisphere kelp beds northward with small fluctuations in SST (Fernández 2011, Pereira et al. 2011, Moy and Christie 2012, Wernberg et al. 2016). Even more studies show kelp declines due to warming (Díez et al. 2012, Harley et al. 2012, Bartsch et al. 2013, Voerman et al. 2013, Krumhansl et al. 2016, Park et al. 2017). The Gulf of Maine (GOM) in the northwestern Atlantic showed unprecedented warming in the 2012 ocean heat wave with temperature anomalies of $\sim 2^{\circ} \mathrm{C}$ above the annual 19982011 climatology (Mills et al. 2013). Furthermore, GOM data shows SST increasing faster than $99 \%$ of the global ocean over the past decade (Pershing et al. 2015). This warming has critical implications for near shore flora and fauna (Lesser 2016), with a northwest migration already observed for some local finfish species (Mills et al. 2013). Furthermore, future climate scenarios, predict global temperature increases of $\sim 2^{\circ} \mathrm{C}$ by 2100 , assuming significant climate action and low-emission scenarios (RCP3$\mathrm{PD})$, while high-emission, non-mitigating future scenarios (RCP8.5) predict increases of up to $6.1^{\circ} \mathrm{C}$ (Rogelj et al. 2012). This is especially critical for intertidal organisms exposed to desiccation stresses with the ebbing tides.

Kelps have a two-stage alternation of heteromorphic generations with a prominent sporophytic blade phase giving rise via meiosis to a microscopic filamentous gametophytic phase. These microscopic stages are critical for the maintenance of the population after annual sporophytes decay (Hoffmann and Santelices 1991, Pereira et al. 2011). It has been shown that the gametophytic stages of S. latissima populations from the western North Atlantic have an upper critical thermal limit of $22^{\circ} \mathrm{C}$, while gametogenesis was suppressed at temperatures above $17^{\circ} \mathrm{C}$ (Redmond 2013). Similarly, S. latissima juvenile sporophyte development was inhibited at $17^{\circ} \mathrm{C}$ and the upper temperature limit for growth was between 18$19^{\circ} \mathrm{C}$ (Kain 1969).

The light saturation point of growth for S. latissima juvenile sporophyte blades has been shown to be at 50-70 $\mu \mathrm{mol}$ photons $\mathrm{m}^{-2} \mathrm{~s}^{-1}$, with an optimum photon flux density of $110 \mu \mathrm{mol}$ photons $\mathrm{m}^{-2} \mathrm{~s}^{-1}$ as the sporophytes approach 6 weeks old (Kain 1969, Egan et al. 1989). Reports for the same species indicate that 1- to 2-year-old fronds show photoinhibition at $250 \mu \mathrm{mol}$ photons $\mathrm{m}^{-2} \mathrm{~s}^{-1}$ (Fortes and Lüning 1980). Wiencke and Fischer (1990) showed that Laminaria digitata adult sporophyte growth was light saturated between 55 and $105 \mu \mathrm{mol}$ photons $\mathrm{m}^{-2} \mathrm{~s}^{-1}$. S. latissima gametophytes grow best at low light levels of $5-20 \mu \mathrm{mol}$ photons $\mathrm{m}^{-2} \mathrm{~s}^{-1}$ (Lee and Brinkhuis 1988) up to 25-50 $\mu$ mol photons $\mathrm{m}^{-2} \mathrm{~s}^{-1}$ (Egan et al. 1989).

A close relative of $S$. latissima, Saccharina angustissima (Collins) Augyte, Yarish \& Neefus is an ecologically, morphologically and genetically distinct kelp found in the GOM (Augyte et al. 2018). Its range spans only 8 nautical miles in the low intertidal on ledges and islands exposed to high wave forces (Mathieson et al. 2008, Mathieson and Dawes 2017, Augyte et al. 2018). The observed recorded SST increases in the GOM and future climate change predictions coupled with the limited distributional range of this rare kelp, place it in danger of extinction from its current habitat. Therefore, the aim of this study was to identify ideal temperature and light conditions for the early developmental stages of this economically important kelp species, S. angustissima (Collins) Augyte, Yarish \& Neefus from Casco Bay, Maine, USA.

\section{MATERIALS AND METHODS}

Two independent experiments tested the effects of temperature and light on the early life stages of $S$. angustissima, specifically gametogenesis, gametophyte growth, and early sporophyte development. The first set of experiments (in 2014) used five temperatures between $7 \pm 1$ and $17 \pm 1^{\circ} \mathrm{C}$ (at $7,9,12,15$, and $17^{\circ} \mathrm{C}$ ), and irradiance of 20, 40, and $80 \mu \mathrm{mol}$ photons $\mathrm{m}^{-2} \mathrm{~s}^{-1}$. The second set of experiments (in 2015) had five temperatures between $3 \pm 1$ to $13 \pm 1^{\circ} \mathrm{C}$ (at $3,5,8,10$, and $13^{\circ} \mathrm{C}$ ), and 3 irradiance levels set at 10,100 , and $200 \mu \mathrm{mol}$ photons $\mathrm{m}^{-2}$ $\mathrm{s}^{-1}$. The photoperiod was set to $12: 12$ light : dark cycle in both experiments.

Sorus tissue was collected from mature blades located in the low intertidal from Bailey's Island, Harpswell, ME 
$\left(43^{\circ} 43.32^{\prime} \mathrm{N}, 69^{\circ} 59.46^{\prime} \mathrm{W}\right)$ during the extreme low tides of October 2014, and again in October 2015. Fall is the peak reproduction period of S. angustissima when about 8595\% of the blades are covered with sorus tissue (Philibert 1990). The sorus tissue was cut, cleaned with an iodine wash, wrapped in paper-towels and allowed to desiccate overnight. The following day the tissue released meiospores when placed in sterile seawater. The resulting concentration of the meiospore solution was, on average, 135,000 meiospores $\mathrm{mL}^{-1}$. Two drops of this meiospore solution ( 27,500 meiospores) were pipetted onto glass cover slips and allowed to germinate in a moisture chamber at $10^{\circ} \mathrm{C}$ in complete darkness, following Egan et al. (1989). After settlement of $48 \mathrm{~h}$, the cover slips were placed into $300 \mathrm{~mL}$ crystalline Pyrex dishes with $250 \mathrm{~mL}$ of sterilized seawater enriched with $0.5 \times$ Provasoli's Enriched Seawater (Provasoli 1968) medium, which was replaced weekly. Each light level and temperature treatment $(n=15)$ had 3 pseudo-replicates for a total of 45 dishes on the gradient table. Temperature measurements were taken with a digital thermometer (Traceable; Control Co., Webster, TX, USA) and light was measured with a Li-Cor LI-1000 (Li-Cor, Inc., Lincoln, NE, USA) photometer. Each week, for a total of 4 successive weeks, a cover slip was randomly chosen from each light / temperature treatment dish and photographed with a camera (PixeLINK, Rochester, NY, USA) attached to a compound microscope. Since 100 gametophytes or sporophytes were counted from each treatment, every coverslip was considered a replicate. Cover slips were discarded after use. Images of meiospore germination, gametophyte and sporophyte length and size were analyzed using ImageJ software (Abràmoff et al. 2004).

Germination was recorded during week 1 as presence / absence data with the observation of germ tube formation, indicating that meiospores had settled and were developing into gametophytes. Sex of developing gametophytes was distinguished based on size and diameter of cells-females were clearly bigger with plumper cells while male filaments were smaller with thinner cells. The female gametophytes were measured by counting the number of cells in each filamentous multicellular structure in week 3 of the experimental treatments. The male gametophytes were measured by taking the length of the longest part of each filamentous multicellular structure at week 3 of all the experimental treatments. Length was used instead of number of cells because the individual male cells were small and indistinguishable within the multicellular filaments. Finally, total length of juvenile sporophytes was measured at week 3 and again at week 4 of each experiment.

Separate data analyses were carried out for the two independent experiments. For count data of kelp spore germination, a chi-square test of independence was run to test if germination at different light levels was dependent on temperature and vice versa.

The effects of light and temperature on the measured responses (size and length) were analyzed by running separate two-way ANOVAs using the generalized linear model with R software (R Core Team 2013). The Levene's test was run to check equal variance and the ShapiroWilk test for normality or residuals. All assumptions for normality and equal variance were met. Significance was defined as $p$-value $<0.05$. When testing statistical differences between irradiance and temperatures, averages were taken for gametophytes and sporophytes that were counted on one coverslip and each coverslip was treated as a replicate. Afterword, significant differences between treatments were found $a$ posteriori with Student-Newman-Keuls (SNK) test using the R package "agricolae."

\section{RESULTS}

\section{Germination rates}

For the higher temperature experiments with ranges $7-17^{\circ} \mathrm{C}$ (from 2014), germination rates were over $90 \%$ for all treatments except for the temperatures 12 and $15^{\circ} \mathrm{C}$ exposed to the highest light levels tested of $80 \mu \mathrm{mol}$ photons $\mathrm{m}^{-2} \mathrm{~s}^{-1}$ (Fig. 1A). During both years of experiments, a significant interaction was found between light and temperature on germination rates (2014; chi-squared $=59.82$, $\mathrm{p}<0.001,2015$; chi-squared $=131.44, \mathrm{p}<0.001)$ (Fig. $1 \mathrm{~A}$ $\& B)$.

\section{Female gametophyte size}

In the higher temperature experiments (from 2014), temperature $(\mathrm{p}=0.0259)$ (Table 1, Fig. $2 \mathrm{~A}$ ) but not light ( $\mathrm{p}$ $=0.3572$ ) were found to significantly affect female gametophyte size. Overall, except for the lowest lows and the highest highs, the sizes of the female gametophytes were very similar and indistinguishable between treatments. The highest mean cell numbers were found in treatment $17^{\circ} \mathrm{C}$ at $40 \mu \mathrm{mol}$ photons $\mathrm{m}^{-2} \mathrm{~s}^{-1}$ with $3.3( \pm 0.6)$ cells (Fig. $2 \mathrm{~A})$. The other treatments ranged in mean cell numbers of 1.2-2.7.

In the second set of experiments with lower temperatures ranges of $3-13^{\circ} \mathrm{C}$ (from 2015), both light $(\mathrm{p}=0.0194)$ 


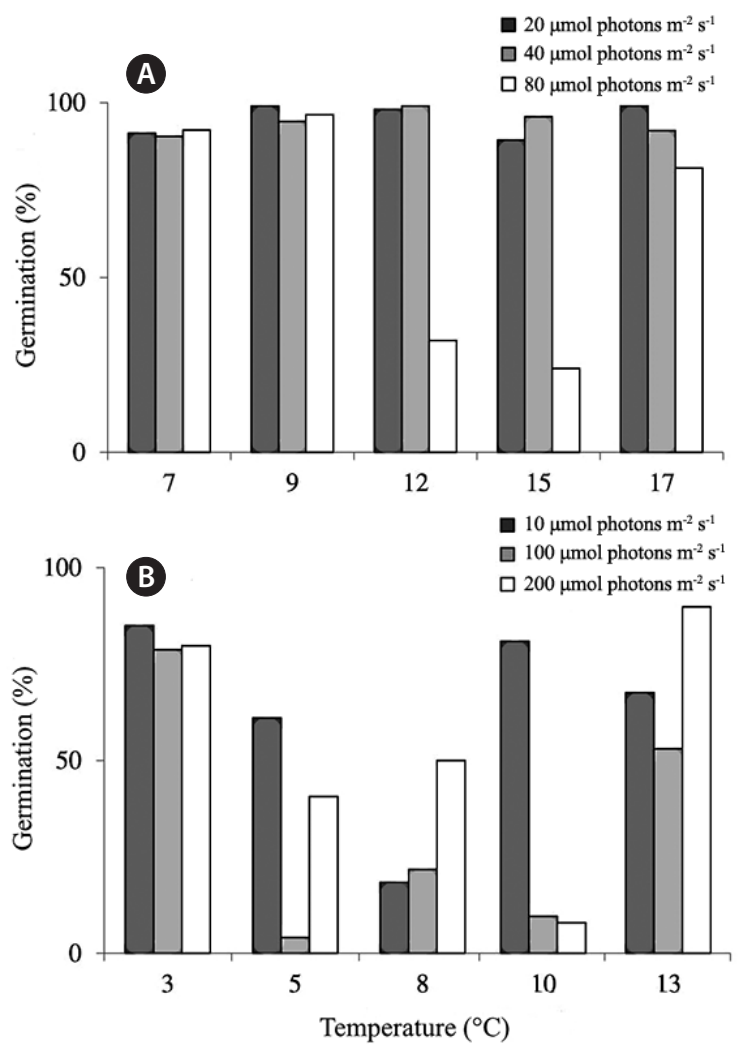

Fig. 1. Results for the 2014 (A) and the 2015 (B) experiments of kelp germination rates after settlement exposed to different temperature and light treatments. Legend indicates light level as $\mu \mathrm{mol}$ photons $\mathrm{m}^{-2} \mathrm{~s}^{-1}$.
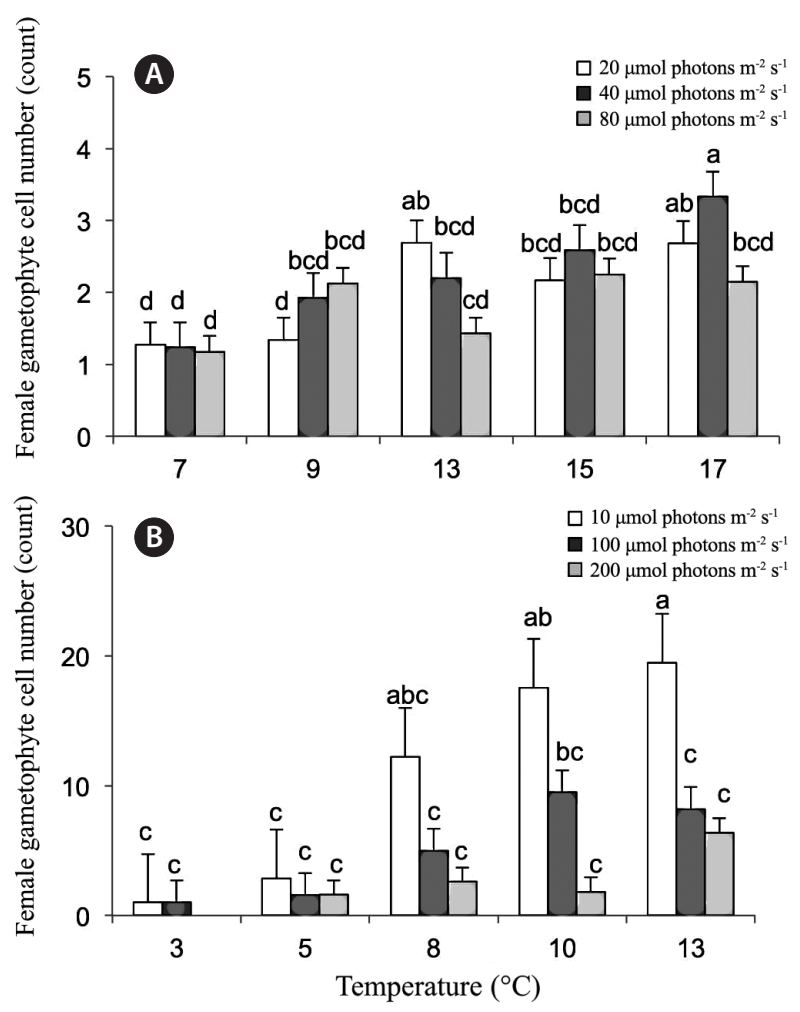

Fig. 2. Results for the 2014 (A) and the 2015 (B) experiment on the effects of temperature and irradiance on cell number of female gametophytes in week 3 (means \pm standard error). Legend indicates photon fluence rates $\left(\mu \mathrm{mol}\right.$ photons $\left.\mathrm{m}^{-2} \mathrm{~s}^{-1}\right)$. Treatment combinations with no letters (a-e) in common were found to be significantly different by Student-Newman-Keuls analysis.

Table 1. Two-way ANOVA table showing statistical significant relationships between Saccharina angustissima gametophyte or sporophyte size with light and temperature as explanatory variables

\begin{tabular}{|c|c|c|c|c|c|}
\hline Response variable & Treatment & df & MS & F & p-value \\
\hline \multirow[t]{3}{*}{ Female gametophytes 2014} & Light & 2 & 0.225 & 1.174 & 0.3572 \\
\hline & Temperature & 4 & 0.9558 & 4.986 & $0.0259^{\mathrm{a}}$ \\
\hline & Residuals & 8 & 0.1917 & - & - \\
\hline \multirow[t]{3}{*}{ Female gametophytes 2015} & Light & 2 & 86.56 & 6.712 & $0.0194^{\mathrm{a}}$ \\
\hline & Temperature & 4 & 64.91 & 5.033 & $0.0253^{\mathrm{a}}$ \\
\hline & Residuals & 8 & 12.9 & - & - \\
\hline \multirow[t]{3}{*}{ Male gametophytes 2014} & Light & 2 & 173.6 & 0.27 & 0.770 \\
\hline & Temperature & 4 & $2,426.4$ & 3.775 & 0.052 \\
\hline & Residuals & 8 & 642.8 & - & - \\
\hline \multirow[t]{3}{*}{ Male gametophytes 2015} & Light & 2 & 2,535 & 2.33 & 0.213 \\
\hline & Temperature & 4 & 1,668 & 1.534 & 0.344 \\
\hline & Residuals & 4 & 1,088 & 0.111 & - \\
\hline \multirow[t]{3}{*}{ Sporophytes week 3, 2014} & Light & 2 & 148 & 0.111 & 0.8966 \\
\hline & Temperature & 4 & 3,791 & 2.839 & 0.0977 \\
\hline & Residuals & 8 & 1,335 & - & - \\
\hline \multirow{3}{*}{ Sporophytes week 4, 2014} & Light & 2 & 20,229 & 6.441 & $0.032^{\mathrm{a}}$ \\
\hline & Temperature & 4 & 72,827 & 23.187 & $<0.001^{\mathrm{a}}$ \\
\hline & Residuals & 6 & 3,141 & - & - \\
\hline \multirow{3}{*}{ Sporophytes week 3, 2015} & Light & 2 & 13,317 & 4.958 & $0.0398^{\mathrm{a}}$ \\
\hline & Temperature & 4 & 885 & 0.329 & 0.8508 \\
\hline & Residuals & 8 & 2,686 & - & - \\
\hline \multirow[t]{3}{*}{ Sporophytes week 4, 2015} & Light & 2 & 40,270 & 5.457 & $0.0373^{\mathrm{a}}$ \\
\hline & Temperature & 4 & 123,932 & 1.773 & 0.2385 \\
\hline & Residuals & 7 & - & - & - \\
\hline
\end{tabular}

${ }^{a}$ Significant values. 


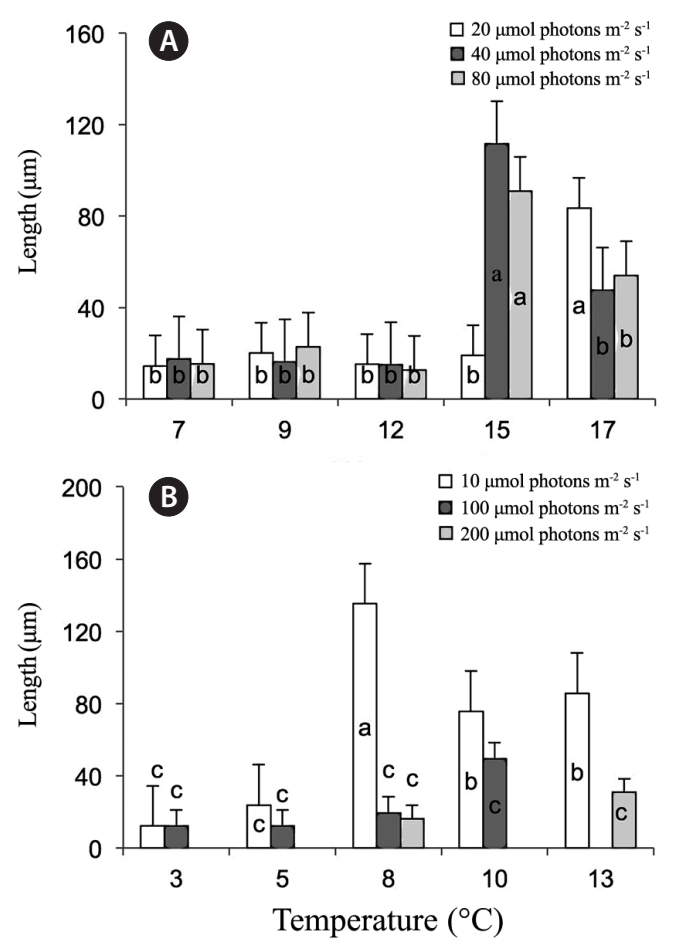

Fig. 3. Results for the 2014 (A) and the 2015 (B) experiment on the effects of temperature and irradiance on filament length ( $\mu \mathrm{m}$, means \pm standard error) of male gametophytes in week 3 . Legend indicates photon fluence rates $\left(\mu \mathrm{mol}\right.$ photons $\mathrm{m}^{-2} \mathrm{~s}^{-1}$ ). Treatment combinations with no letters (a-e) in common were found to be significantly different by Student-Newman-Keuls analysis.

(Table 1, Fig. 2B) and temperature $(\mathrm{p}=0.0253)$ were found to have significant effects on female gametophyte size. The largest female gametophytes were found at the lowest light levels of $10 \mu \mathrm{mol}$ photons $\mathrm{m}^{-2} \mathrm{~s}^{-1}$ with mean number of cells averaging at $12.2 \pm 4.3,17.6 \pm 3.2$, and $19.5 \pm 5.3$ for temperatures 8,10 , and $13^{\circ} \mathrm{C}$, respectively. The coldest temperatures $\left(3\right.$ and $\left.5^{\circ} \mathrm{C}\right)$ showed low growth at all light levels. Growth was not observed at the coldest treatment $\left(3^{\circ} \mathrm{C}\right)$ coupled with the highest light level $(200$ $\mu \mathrm{mol}$ photons $\mathrm{m}^{-2} \mathrm{~s}^{-1}$ ). While year to year variation was not tested in the analysis, it was observed that overall, female gametophytes grew larger than in the first set of experiments.

\section{Male gametophyte size}

For the higher temperature experiments (from 2014), temperature had a slight significant effect on male gametophyte length $(p=0.052)$ (Table 1 , Fig. 3A) while light was not significant $(\mathrm{p}=0.770)$. The largest male gametophytes were found at $15^{\circ} \mathrm{C}$ at 40 and 80 photons $\mathrm{m}^{-2} \mathrm{~s}^{-1}$ with lengths of $111.6 \pm 13.9$ and $91.0 \pm 17.0 \mu \mathrm{m}$, respec-

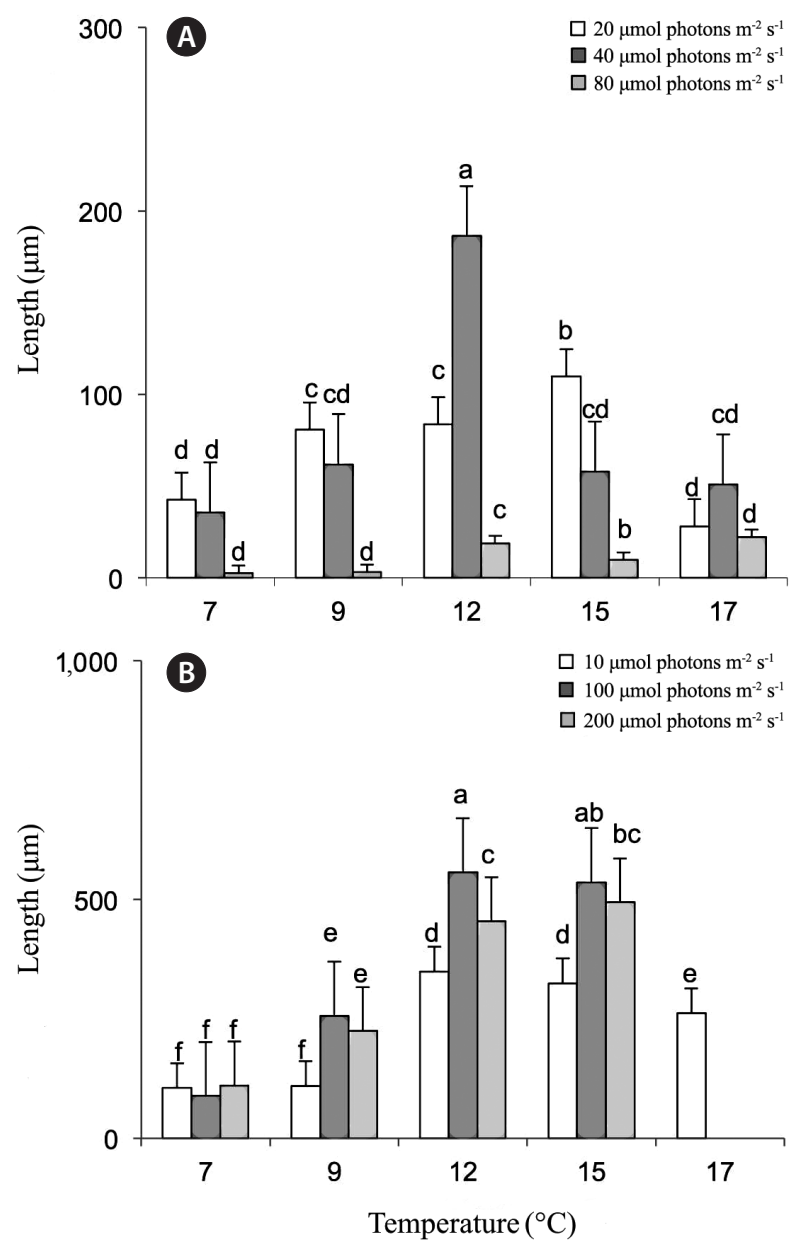

Fig. 4. Effects of temperature and irradiance on kelp sporophyte lengths ( $\mu \mathrm{m}$, means \pm standard error) during 2014 in treatment $7-17^{\circ} \mathrm{C}$ for week $3(\mathrm{~A})$ and week $4(\mathrm{~B})$. Legend indicates photon fluence rates $\left(\mu \mathrm{mol}\right.$ photons $\left.\mathrm{m}^{-2} \mathrm{~s}^{-1}\right)$. Treatment combinations with no letters (a-e) in common were found to be significantly different by Student-Newman-Keuls analysis.

tively and at $17^{\circ} \mathrm{C}$ at 20 photons $\mathrm{m}^{-2} \mathrm{~s}^{-1}$ with a length of $83.4 \pm 12.7 \mu \mathrm{m}$. All other means of the other treatments were not significantly different from each other with average ranges of $12.6-54.0 \mu \mathrm{m}$.

In the second set of experiments (from 2015), neither temperature $(\mathrm{p}=0.344)$ (Table 1 , Fig. 3B) nor light $(\mathrm{p}=$ 0.213 ) were found to have a significant effect on male gametophyte length. At $8^{\circ} \mathrm{C}$, a spike in the length of gametophytes grown at $10 \mu \mathrm{mol}$ photons $\mathrm{m}^{-2} \mathrm{~s}^{-1}$ of $135 \pm 13.4$ $\mu \mathrm{m}$ was observed. The second largest size sets were again measured at the lowest light level tested at temperatures of 10 and $13^{\circ} \mathrm{C}$ with lengths of $75.6 \pm 6.6$ and $85.6 \pm 8.4$ $\mu \mathrm{m}$, respectively. The rest of the means were not significantly different from each other. 

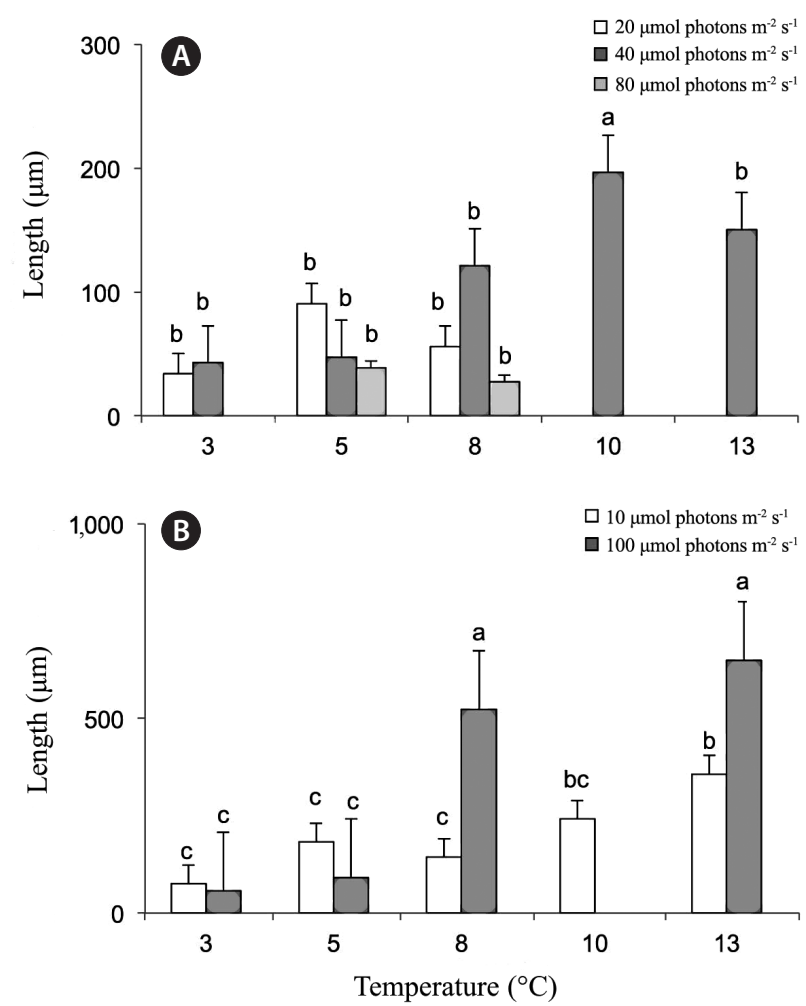

Fig. 5. Effects of temperature and irradiance on kelp sporophyte lengths ( $\mu \mathrm{m}$, means \pm standard error) during 2015 in treatment $3-13^{\circ} \mathrm{C}$ for weeks $3(\mathrm{~A})$ and 4 (B). Legend indicates photon fluence rates $\left(\mu \mathrm{mol}\right.$ photons $\left.\mathrm{m}^{-2} \mathrm{~s}^{-1}\right)$. In week 3 , there were no observable sporophytes, only gametophytes in 10 and $13^{\circ} \mathrm{C}$ at 10 and $200 \mu \mathrm{mol}$ photons $\mathrm{m}^{-2} \mathrm{~s}^{-1}$. In week 4 , there were no observable sporophytes in light treatment $200 \mu \mathrm{mol}$ photons $\mathrm{m}^{-2} \mathrm{~s}^{-1}$ with all temperature treatments tested. Data is not available for week 4 , temperature treatment $10^{\circ} \mathrm{C}$ at $100 \mu \mathrm{mol}$ photons $\mathrm{m}^{-2} \mathrm{~s}^{-1}$. Treatment combinations with no letters (a-e) in common were found to be significantly different by StudentNewman-Keuls analysis.

\section{Sporophyte growth}

For the first set of experiments (from 2014), some sporophyte development was already observed during week 2 , but measurements only started in week 3 . Both light and temperature were found to have significant effects of sporophyte length only in week 4 not in week 3 (week 4 : light, $\mathrm{p}=0.032$; temperature, $\mathrm{p}<0.001$; week 3 : light, $\mathrm{p}=$ 0.8966; temperature, $p=0.0977$ ) (Table 1, Fig. 4A \& B). In both weeks 3 and 4 , the largest sporophytes were found in treatment of $12^{\circ} \mathrm{C}$ and $40 \mu \mathrm{mol}$ photons $\mathrm{m}^{-2} \mathrm{~s}^{-1}$ at mean lengths of $186 \pm 14 \mu \mathrm{m}$ in week 3 , growing to lengths of $557 \pm 39 \mu \mathrm{m}$ by week 4 . In week 4 , large sporophytes were also measured at $15^{\circ} \mathrm{C}$ and $40 \mu \mathrm{mol}$ photons $\mathrm{m}^{-2} \mathrm{~s}^{-1}$ conditions with lengths of $536 \pm 40 \mu \mathrm{m}$. At $17^{\circ} \mathrm{C}$, only a few sporophytes were produced under the lowest light levels, while the other light conditions produced only gametophytes. The coldest temperature tested, $7^{\circ} \mathrm{C}$, produced very small sporophytes.

For the second set of experiments (from 2015) light but not temperature were found to exert a significant effect on sporophyte length in both weeks 3 and 4 (week 3 : light, $\mathrm{p}=0.0398$; temperature, $\mathrm{p}=0.8508$; week 4 : light, $\mathrm{p}$ $=0.0373$; temperature, $p=0.2385$ ) (Table 1 , Fig. $5 \mathrm{~A} \& \mathrm{~B}$ ). In week 3 , only gametophytes, no sporophytes, were observed at the following conditions; $3^{\circ} \mathrm{C}$ for $200 \mu \mathrm{mol}$ photons $\mathrm{m}^{-2} \mathrm{~s}^{-1}$ and 10 and $13^{\circ} \mathrm{C}$ for 10 and $200 \mu \mathrm{mol}$ photons $\mathrm{m}^{-2} \mathrm{~s}^{-1}$. Longest sporophytes were found at $10^{\circ} \mathrm{C}$ at 100 $\mu \mathrm{mol}$ photons $\mathrm{m}^{-2} \mathrm{~s}^{-1}$ at mean lengths of $197 \pm 19 \mu \mathrm{m}$. In week 4 , there were no sporophytes, only gametophytes, observed for the highest light treatments tested of 200 $\mu \mathrm{mol}$ photons $\mathrm{m}^{-2} \mathrm{~s}^{-1}$. Treatments of 8 and $13^{\circ} \mathrm{C}$ at 100 $\mu \mathrm{mol}$ photons $\mathrm{m}^{-2} \mathrm{~s}^{-1}$ produced the largest sporophytes at $523 \pm 24$ and $650 \pm 18 \mu \mathrm{m}$, respectively. Data is missing for week 4 , temperature treatment $10^{\circ} \mathrm{C}$ at $100 \mu \mathrm{mol}$ photons $\mathrm{m}^{-2} \mathrm{~s}^{-1}$ so it is unclear if the results from week 3 would have carried over.

\section{DISCUSSION}

Kelp meiospores and gametophytes are particularly vulnerable to fluctuations in environmental conditions (Müller et al. 2008, Zhang et al. 2013) and it is therefore critical for kelp physiology and biogeography to understand how these microscopic phases respond in light of changing climate scenarios. In general, high germination rates $(90 \%)$ of kelp of meiospores were observed at temperatures ranging from $7-17^{\circ} \mathrm{C}$ in light conditions of 20$80 \mu \mathrm{mol}$ photons $\mathrm{m}^{-2} \mathrm{~s}^{-1}$ except for at 12 and $15^{\circ} \mathrm{C}$. In the second experiment, the pattern for germination rates is not as obvious and warrants further study.

In the low intertidal in Casco Bay, Maine, Saccharina angustissima reaches its peak in sorus and thus meiospore production and release in October to November (Philibert 1990, personal observation) when SST are at $10-13^{\circ} \mathrm{C}$ (Fig. 6A). The coldest air temperatures follow during January through April dropping to lows of $4 \pm 2^{\circ} \mathrm{C}$ (Fig. 6B). In this study, the coldest temperatures tested at $3-5^{\circ} \mathrm{C}$, showed trends of a reduction in size of male and female gametophytes, regardless of light level. One-celled female gametophytes still produced an egg that allowed fertilization to occur as sporophytes were observed in the subsequent week in those conditions. Furthermore, a colder tolerance by female gametophytes was observed, which in the field, may translate to earlier growth rates 


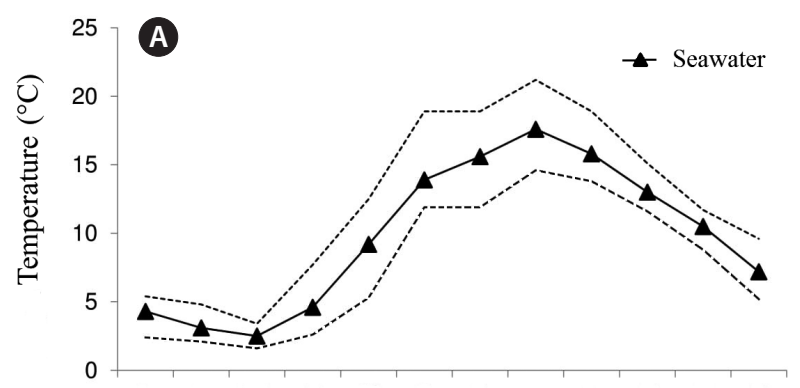

Jan Feb Mar Apr May Jun Jul Aug Sep Oct Nov Dec

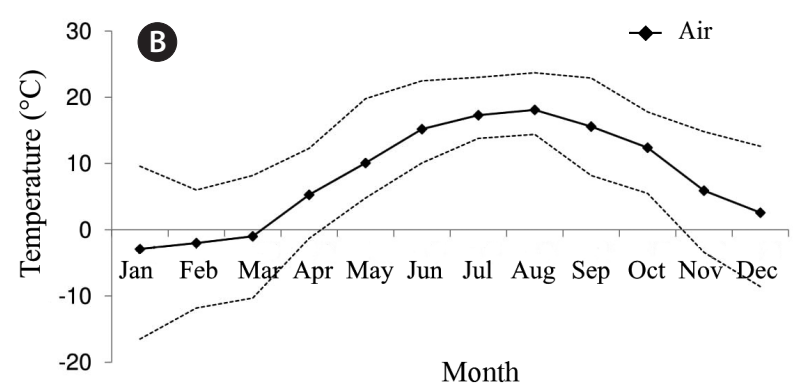

Fig. 6. Monthly seawater $(\mathrm{A})$ and air $(\mathrm{B})$ temperature $\left({ }^{\circ} \mathrm{C}\right)$ averages for 2014 for Casco Bay, Maine. Dashed lines represent average high and lows for the months. Data obtained from NERACOOS buoy 44007.

for females compared to males. Previous work shows that S. latissima female gametophytes may be more sensitive to increases in temperature, and higher temperatures may produce more male than female gametophytes (Lee and Brinkhuis 1988, Egan et al. 1989). For the kelp Laminaria ochroleuca, low light levels and temperatures of 10$12^{\circ} \mathrm{C}$ were ideal for producing female gametophytes of more than 20 cells in the warm temperate species (Price et al. 2003). While gametophyte development of the cold temperate kelp, Saccorhiza polyschides, in Portugal was not observed at very high temperatures of $25^{\circ} \mathrm{C}$ (Pereira et al. 2011).

In the field, the S. angustissima kelp gametophytes must have temperature triggers that stimulate growth when SST reach above $7^{\circ} \mathrm{C}$. This has implications for future reproductive success of this species in relation to climate change. For example, if SST warming of a few degrees occurs during the winter, the gametophytes might have a competitive advantage in production of biomass, especially under low light conditions. Yarish et al. (1990) reported a reduction in gametangia and sporophyte production and development of Saccharina longicruris at $5^{\circ} \mathrm{C}$, especially under high photon fluence rates $(>40$ $\mu \mathrm{mol}$ photons $\mathrm{m}^{-2} \mathrm{~s}^{-1}$ ), but inter-annual variation has also been reported (Egan et al. 1989). In this study, longer female gametophyte filaments of 18-19 cells were measured in some of the warmer conditions at 10 and $13^{\circ} \mathrm{C}$; temperatures that would only be observed in the field starting in May. Mature S. angustissima sporophytes have been collected at the site in June, but it is unknown how early in the season blade development commences. According to typical kelp life cycle phenology, spores settle within hours to a few days of release, gametes are produced over the next week and fertilization occurs shortly after leading to the development of a zygote and eventually to a macroscopic sporophyte (Reed et al. 1992, Schiel and Foster 2006). For S. angustissima growing in the high wave environment, it is predicted that meiospore settlement occurs rapidly after release and that fertilization of gametes soon after. However, additional research is needed to identify the mechanisms for meiospore settlement and fertilization success including for how long, if at all, filamentous gametophyte banks persist over the winter into spring. Our results confirm that optimal $S$. angustissima gametophyte growth in culture conditions is at temperatures ranging $8-13^{\circ} \mathrm{C}$ with light levels from 10 to $100 \mu \mathrm{mol}$ photons $\mathrm{m}^{-2} \mathrm{~s}^{-1}$ suggesting that if gametophytes persist over the winter, they are able to grow into large filaments when both air and water temperatures are closer to their optima observed in lab experiments.

Kelp gametophytes have the capacity to withstand long periods of darkness and thus have exceptionally low-light demands (Bartsch et al. 2008). Laminaria digitata, L. ochroleuca, and Laminaria hyperborea gametophytes become fertile at irradiance as low as 2-4.5 $\mu \mathrm{mol}$ photons $\mathrm{m}^{-2} \mathrm{~s}^{-1}$ (Tom Dieck 1992). In this study, the lowest light level tested, $10 \mu \mathrm{mol}$ photons $\mathrm{m}^{-2} \mathrm{~s}^{-1}$, produced some of the highest growth for gametophytes. Female gametophytes showed some growth and development at the highest light levels, $200 \mu \mathrm{mol}$ photons $\mathrm{m}^{-2} \mathrm{~s}^{-1}$, in all but at the coldest $\left(3^{\circ} \mathrm{C}\right)$ condition. However, the highest light condition was detrimental to some of the male gametophytes and these grew only under the temperature conditions of 8 and $13^{\circ} \mathrm{C}$. Male gametophytes, therefore, are able to tolerate some high light but only when coupled with their optimal temperature conditions. Previous studies document light saturation at $70 \mu \mathrm{mol}$ photons $\mathrm{m}^{-2} \mathrm{~s}^{-1}$ for S. latissima (Fortes and Lüning 1980). Similarly, in this study, high light was detrimental to juvenile S. angustissima sporophyte development. While in week 3 some sporophytes were observed at the highest light tested $\left(200 \mu \mathrm{mol}\right.$ photons $\left.\mathrm{m}^{-2} \mathrm{~s}^{-1}\right)$ at 5 and $8^{\circ} \mathrm{C}$, by week 4 there were no sporophytes observed under these light conditions. However, light levels of $100 \mu \mathrm{mol}$ photons $\mathrm{m}^{-2}$ $\mathrm{s}^{-1}$ still produced large sporophytes. The intertidal kelp, 
S. angustissima might be better adapted to higher light levels than the subtidal S. latissima and thus might have a competitive advantage succeeding in future scenarios when facing changing environmental conditions.

The largest sporophytes were observed at temperatures 12 and $15^{\circ} \mathrm{C}$ for the first set of experiments and again at $13^{\circ} \mathrm{C}$ for the second set. The highest temperature tested of $17^{\circ} \mathrm{C}$ showed slight sporophyte development in week 3 for all light levels, but by week 4 only at the lowest light level. Therefore, high temperatures coupled with high light levels were detrimental to juvenile sporophyte growth and development. Within its current restricted distribution, in Casco Bay, Maine, sea-surface and air temperatures above $17^{\circ} \mathrm{C}$ are experienced by fully developed adult kelp sporophytes in late summer for brief periods during emersion. During the months of August and September, the SST averages are up to $17 \pm 3^{\circ} \mathrm{C}$, while the air temperature reaches highs of $18 \pm 6^{\circ} \mathrm{C}$ (Fig. $6 \mathrm{~A}$ \& B). For both experiments, the cold temperature treatments $\left(3-7^{\circ} \mathrm{C}\right)$ produced stunted sporophytes. Literature shows a broad range of optimal temperatures for S. latissima sporophyte growth of $10-15^{\circ} \mathrm{C}$ in temperate regions (Fortes and Lüning 1980, Yarish et al. 1990) to as low as $5-10^{\circ} \mathrm{C}$ growth optima in Arctic regions (Park et al. 2017). In Alaska, decreased settlement and growth was observed for S. latissima spores and gametophytes when exposed to temperatures of $21^{\circ} \mathrm{C}$ and low salinity, however, the kelp was overall resilient to temperature changes even when these were extreme and abrupt (Lind and Konar 2017). In the field, an additional stress for S. angustissima is exposure to below freezing air temperatures during winter low tides that may drop to as low as $-2^{\circ} \mathrm{C}$ (Fig. 6B). The results presented in this study show that sporophyte development was stunted at the coldest and hottest temperatures tested alluding to an optimal temperature for growth. The optimal temperature range was found to be $8-15^{\circ} \mathrm{C}$. Specifically, temperature and light conditions for sporophyte development were 12 and $15^{\circ} \mathrm{C}$ at both 40 and $80 \mu \mathrm{mol}$ photons $\mathrm{m}^{-2} \mathrm{~s}^{-1}$ and at 8 and $13^{\circ} \mathrm{C}$ at $80 \mu \mathrm{mol}$ photons $\mathrm{m}^{-2} \mathrm{~s}^{-1}$.

It is critical for kelp to be able to acclimate to shortterm heat stress and seasonal temperature shifts, especially for kelp near their physiological temperature limits (Wernberg et al. 2010, Bartsch et al. 2013). There is little experimental evidence suggesting that increasing SSTs will allow species to evolve fast enough to stay within current geographic zones because of global climatic change (Parmesan 2006). The kelp S. angustissima appears to have limited dispersal capability and grows in a radius of eight nautical miles (Mathieson et al. 2008, Mathieson and Dawes 2017, Augyte et al. 2018). This study indicates that temperatures above $15^{\circ} \mathrm{C}$ inhibit S. angustissima sporophyte formation, especially at high irradiance and thus, warming SST could limit its ability to retreat northward if it becomes pushed out of its optimal temperature range in the Gulf of Maine if the current warming trend of $\left(0.23^{\circ} \mathrm{C}^{1}\right)$ continues as has been observed in the last decade (Pershing et al. 2015). Overall, the filamentous gametophytes were shown to be more tolerant of higher temperatures than juvenile sporophytes especially when coupled with high irradiance. Warming temperatures could thus shift reproduction times to earlier in the season and as well as lead to more observed production during the spring and fall seasons as opposed to the summer months when this kelp is at its current peak blade production.

\section{ACKNOWLEDGEMENTS}

A special thanks to N. Ramakrishna, A. Ferro, and Y. Huo for assistance with gradient plate experiments, A. Lamb and J. K. Kim for the review of manuscript, and J. Kübler for statistical expertise. This work was supported by The Maine Aquaculture Innovation Center (Project No. 15-11), The Francis Rice Trainer Endowment Fund to the Dept. of Ecology and Evolutionary Biology and the Connecticut Museum of Natural History, Sigma Xi Grants-inAid of Research, The Woman's Seamen's Friend Society of Connecticut, and USDA/National Institute of Food and Agriculture (Project Award \# 2014-70007-22546).

\section{REFERENCES}

Abràmoff, M. D., Magalhães, P. J. \& Ram, S. J. 2004. Image processing with ImageJ. Biophotonics Int. 11:36-42.

Adey, W. H. \& Steneck, R. S. 2001. Thermogeography over time creates biogeographic regions: a temperature/scale/ time-integrated model and an abundance-weighted test for benthic marine algae. J. Phycol. 37:677-698.

Augyte, S., Lewis, L., Lin, S., Neefus, C. D. \& Yarish, C. 2018. Speciation in the exposed intertidal zone: the case of Saccharina angustissima comb. nov. \& stat. nov. (Laminariales, Phaeophyceae). Phycologia 57:100-112.

Bartsch, I., Vogt, J., Pehlke, C. \& Hanelt, D. 2013. Prevailing sea surface temperatures inhibit summer reproduction of the kelp Laminaria digitata at Helgoland (North Sea). J. Phycol. 49:1061-1073.

Bartsch, I., Wiencke, C., Bischof, K., Buchholz, C. M., Buck, 
B. H., Eggert, A., Feuerpfeil, P., Hanelt, D., Jacobsen, S., Karez, R., Karsten, U., Molis, M., Roleda, M. Y., Schubert, H., Schumann, R., Valentin, K., Weinberger, F. \& Wiese, J. 2008. The genus Laminaria sensu lato: recent insights and developments. Eur. J. Phycol. 43:1-86.

Colvard, N. B., Carrington, E. \& Helmuth, B. 2014. Temperature-dependent photosynthesis in the intertidal alga Fucus gardneri and sensitivity to ongoing climate change. J. Exp. Mar. Biol. Ecol. 458:6-12.

Díez, I., Muguerza, N., Santolaria, A., Ganzedo, U. \& Gorostiaga, J. M. 2012. Seaweed assemblage changes in the eastern Cantabrian Sea and their potential relationship to climate change. Estuar. Coast. Shelf Sci. 99:108-120.

Duggins, D. O., Gómez-Buckley, M. C., Buckley, R. M., Lowe, A. T., Galloway, A. W. E. \& Dethier, M. N. 2016. Islands in the stream: kelp detritus as faunal magnets. Mar. Biol. 163:17.

Egan, B., Vlasto, A. \& Yarish, C. 1989. Seasonal acclimation to temperature and light in Laminaria longicruris de la Pyl. (Phaeophyta). J. Exp. Mar. Biol. Ecol. 129:1-16.

Fernández, C. 2011. The retreat of large brown seaweeds on the north coast of Spain: the case of Sacchorhiza polyschides. Eur. J. Phycol. 46:352-360.

Fortes, M. D. \& Lüning, K. 1980. Growth rates of North Sea macroalgae in relation to temperature, irradiance and photoperiod. Helgol. Meeresunters. 34:15-29.

Harley, C. D. G., Anderson, K. M., Demes, K. W., Jorve, J. P., Kordas, R. L., Coyle, T. A. \& Graham, M. H. 2012. Effects of climate change on global seaweed communities. J. Phycol. 48:1064-1078.

Hoffmann, A. J. \& Santelices, B. 1991. Banks of algal microscopic form: hypothesis of their functioning and comparisons with seed banks. Mar. Ecol. Prog. Ser. 79:185194.

Kain, J. 1969. The biology of Laminaria hyperborea. V. Comparison with early stages of competitors. J. Mar. Biol. Assoc. UK. 49:455-473.

Kim, J. K., Kraemer, G. P. \& Yarish, C. 2015. Use of sugar kelp aquaculture in Long Island Sound and the Bronx River Estuary for nutrient extraction. Mar. Ecol. Prog. Ser. 531:155-166.

Kim, J. K., Yarish, C., Hwang, E. K., Park, M. \& Kim, Y. 2017. Seaweed aquaculture: cultivation technologies, challenges and its ecosystem services. Algae 32:1-13.

Krumhansl, K. A., Okamoto, D. K., Rassweiler, A., Novak, M., Bolton, J. J., Cavanaugh, K. C., Connell, S. D., Johnson, C. R., Konar, B., Ling, S. D., Micheli, F., Norderhaug, K. M., Pérez-Matus, A., Sousa-Pinto, I., Reed, D. C., Salomon, A. K., Shears, N. T., Wernberg, T., Anderson, R. J., Barrett, N. S., Buschmann, A. H., Carr, M. H., Caselle, J. E., Der- rien- Courtel, S., Edgar, G. J., Edwards, M., Estes, J. A., Goodwin, C., Kenner, M. C., Kushner, D. J., Moy, F. E., Nunn, J., Steneck, R. S., Vásquez, J., Watson, J., Witman, J. D. \& Byrnes, J. E. K. 2016. Global patterns of kelp forest change over the past half-century. Proc. Natl. Acad. Sci. U. S. A. 113:13785-13790.

Krumhansl, K. A. \& Scheibling, R. E. 2012. Production and fate of kelp detritus. Mar. Ecol. Prog. Ser. 467:281-302.

Lee, J. A. \& Brinkhuis, B. H. 1988. Seasonal light and temperature interaction effects on development of Laminaria saccharina (Phaeophyta) gametophytes and juvenile sporophytes. J. Phycol. 24:181-191.

Lesser, M. P. 2016. Climate change stressors cause metabolic depression in the blue mussel, Mytilus edulis, from the Gulf of Maine. Limnol. Oceanogr. 61:1705-1717.

Lind, A. C. \& Konar, B. 2017. Effects of abiotic stressors on kelp early life-history stages. Algae 32:223-233.

Lüning, K. 1990. Seaweeds: their environment, biogeography, and ecophysiology. John Wiley \& Sons, Inc., New York, $527 \mathrm{pp}$.

Mathieson, A. C. \& Dawes, C. J. 2017. Seaweeds of the Northwest Atlantic. University of Massachusetts Press, Amherst, MA, $798 \mathrm{pp}$.

Mathieson, C., Hehre, E. J., Dawes, C. J. \& Neefus, C. D. 2008. An historical comparison of seaweed populations from Casco Bay, Maine. Rhodora 110:1-102.

Mills, K. E., Pershing, A. J., Brown, C. J., Chen, Y., Chiang, F. -S., Holland, D. S., Lehuta, S., Nye, J. A., Sun, J. C., Thomas, A. C. \& Wahle, R. A. 2013. Fisheries management in a changing climate: lessons from the 2012 ocean heat wave in the Northwest Atlantic. Oceanography 26:191195.

Moy, F. E. \& Christie, H. 2012. Large-scale shift from sugar kelp (Saccharina latissima) to ephemeral algae along the south and west coast of Norway. Mar. Biol. Res. 8:309-321.

Müller, R., Wiencke, C. \& Bischof, K. 2008. Interactive effects of UV radiation and temperature on microstages of Laminariales (Phaeophyceae) from the Arctic and North Sea. Clim. Res. 37:203-213.

Park, J., Kim, J. K., Kong, J. -A., Depuydt, S., Brown, M. T. \& Han, T. 2017. Implications of rising temperatures for gametophyte performance of two kelp species from Arctic waters. Bot. Mar. 60:39-48.

Parmesan, C. 2006. Ecological and evolutionary responses to recent climate change. Annu. Rev. Ecol. Evol. Syst. 37:637-669.

Pereira, T. R., Engelen, A. H., Pearson, G. A., Serrão, E. A., Destombe, C. \& Valero, M. 2011. Temperature effects on the microscopic haploid stage development of Lami- 
naria ochroleuca and Saccorhiza polyschides, kelps with contrasting life histories. Cah. Biol. Mar. 52:395-403.

Pershing, A. J., Alexander, M. A., Hernandez, C. M., Kerr, L. A., Le Bris, A., Mills, K. A., Nye, J. A., Record, N. R., Scannell, H. A., Scott, J. D., Sherwood, G. D. \& Thomas, A. C. 2015. Slow adaptation in the face of rapid warming leads to collapse of the Gulf of Maine cod fishery. Science 350:809-812.

Philibert, J. P. 1990. A study of the morphology, phenology, and ecology of Laminaria saccharina forma angustissima. M.S. thesis, University of Massachusetts, Amherst, MA, 76 pp.

Price, T. D., Qvarnström, A. \& Irwin, D. E. 2003. The role of phenotypic plasticity in driving genetic evolution. Proc. R. Soc. Lond. B 270:1433-1440.

Provasoli, L. 1968. Media and prospects for the cultivation of marine algae. In Watanabe, A. \& Hattori, A. (Eds.) Cultures and Collections of Algae, Proc. U.S. Japan Conf., Japanese Society Plant Physiology, Hakone, pp. 63-75.

R Core Team. 2013. R: a language and environment for statistical computing. R Foundation for Statistical Computing, Vienna, Austria.

Redmond, S. 2013. Effects of increasing temperature and ocean acidification on the microstages of two populations of Saccharina latissima in the Northwest Atlantic. M.S. thesis, University of Connecticut, Storrs, CT, 51 pp.

Reed, D. C., Amsler, C. D. \& Ebeling, A. W. 1992. Dispersal in kelps: factors affecting spore swimming and competency. Ecology 73:1577-1585.

Rogelj, J., Meinshausen, M. \& Knutti, R. 2012. Global warming under old and new scenarios using IPCC climate sensitivity range estimates. Nat. Clim. Chang. 2:248-253.

Rose, J. M., Bricker, S. B., Deonarine, S., Ferreira, J. G., Getchis, T., Grant, J., Kim, J. K., Krumholz, J. S., Kraemer, G. P., Stephenson, K., Wikfors, G. H. \& Yarish, C. 2015. Nutrient bioextraction. In Meyers, R. A. (Ed.) Encyclopedia of Sustainability Science and Technology. Springer, New York, pp. 1-33.

Schiel, D. R. \& Foster, M. S. 2006. The population biology of large brown seaweeds: ecological consequences of multiphase life histories in dynamic coastal environments. Annu. Rev. Ecol. Evol. S. 37:343-372.

Smale, D. A., Burrows, M. T., Moore, P., O'Connor, N. \&
Hawkins, S. J. 2013. Threats and knowledge gaps for ecosystem services provided by kelp forests: a northeast Atlantic perspective. Ecol. Evol. 3:4016-4038.

Steneck, R. S., Graham, M. H., Bourque, B. J., Corbett, D., Erlandson, J. M., Estes, J. A. \& Tegner, M. J. 2002. Kelp forest ecosystems: biodiversity, stability, resilience and future. Environ. Conserv. 29:436-459.

tom Dieck (Bartsch), I. 1992. North Pacific and North Atlantic digitate Laminaria species (Phaeophyta): hybridization experiments and temperature responses. Phycologia 31:147-163.

Voerman, S. E., Llera, E. \& Rico, J. M. 2013. Climate driven changes in subtidal kelp forest communities in NW Spain. Mar. Environ. Res. 90:119-127.

Wells, M. L., Potin, P., Craigie, J. S., Raven, J. A., Merchant, S. S., Helliwell, K. E., Smith, A. G., Camine, M. E. \& Brawley, S. H. 2017. Algae as nutritional and functional food sources: revisiting our understanding. J. Appl. Phycol. 29:949-982.

Wernberg, T., Bennett, S., Babcock, R. C., de Bettignies, T., Cure, K., Depczynski, M., Dufois, F., Fromont, J., Fulton, C. J., Hovey, R. K., Harvey, E. S., Holmes, T. H., Kendrick, G. A., Radford, B., Santana-Garcon, J., Saunders, B. J., Smale, D. A., Thomsen, M. S., Tuckett, C. A., Tuya, F, Vanderklift, M. A. \& Wilson, S. 2016. Climate-driven regime shift of a temperate marine ecosystem. Science 353:169-172.

Wernberg, T., Thomsen, M. S., Tuya, F., Kendrick, G. A., Staehr, P. A. \& Toohey, B. D. 2010. Decreasing resilience of kelp beds along a latitudinal temperature gradient: potential implications for a warmer future. Ecol. Lett. 13:685-694.

Wiencke, C. \& Fischer, G. 1990. Growth and stable carbon isotope composition of cold-water macroalgae in relation to light and temperature. Mar. Ecol. Prog. Ser. 65:283-292.

Yarish, C., Penniman, C. A. \& Egan, B. 1990. Growth and reproductive responses of Laminaria longicruris (Laminariales, Phaeophyta) to nutrient enrichment. Hydrobiologia 204/205:505-511.

Zhang, L., Cui, C., Li, X., Zhang, Z., Luo, S., Liang, G., Liu, Y. \& Yang, G. 2013. Effect of temperature on the development of Saccharina japonica gametophytes. J. Appl. Phycol. 23:261-267. 